\title{
Pemberdayaan Masyarakat Melalui Pengembangan Budidaya Ikan Air Tawar di Kabupaten Pasaman
}

\author{
Dadang Mashur, Fadel M. Azhari, Putri Zahira \\ Fakultas Ilmu Sosial dan Ilmu Politik Universitas Riau, Indonesia \\ Program Studi Administrasi Publik \\ e-mail:da2nk_mashur@yahoo.co.id
}

\begin{abstract}
Abstrak
Permintaan ikan air tawar di Provinsi Sumatera Barat Kabupaten Pasaman masih tergolong sangat tinggi sedangkan ketersedian ikan air tawar sangat kurang. Hal ini melatarbelakangi pemerintah Kabupaten Pasaman membuat program pemberdayakan masyarakat di bidang budidaya ikan air tawar dengan tujuan untuk meningkatkan hasil produksi ikan air tawar yang berkualitas sekaligus meningkatkan kesejahteraan masyarakat yang saat ini masih berada dibawah garis kemiskinan. Tujuan riset ini adalah untuk mengetahui keberhasilan pemberdayaan masyarakat dalam budidaya ikan air tawar oleh pemerintah Kabupaten Pasaman. Metode penelitian yang digunakan adalah metode kualitattif dengan pendekatan deskriptif, dengan teknik pengumpulan data menggunakan studi literatur, serta teknik keabsahan data menggunakan triangulasi data. Hasil penelitian menunjukkan bahwa pemberdayaan masyarakat dibidang budidaya ikan air tawar yang dilakukan pemerintah Pasaman bersama masyarakat tergolong berhasil dengan semakin meningkatnya hasil produksi ikan air tawar yang dihasilkan dari 46.809 ton pada tahun 2013 menjadi 51.827 ton pada tahun 2018, sehingga menaikkan tingkat kesejahteraan masyarakat yang sebelumnya berpenghasilan kurang dari Rp 10 juta saat ini telah meningkat menjadi Rp 25 juta per tiga bulan, dan menjadikan Kabupaten Pasaman sebagai salah satu daerah terbaik dalam budidaya ikan air tawar di Indonesia.
\end{abstract}

Keywords: Budidaya Ikan, Pemberdayaan Masyarakat

\begin{abstract}
Demand for freshwater fish in the province of West Sumatera Pasaman District is still relatively high while the availability freshwater fish is very lacking. This is backed by the government of Pasaman Regency to make programs to empower people in the field of freshwater fish aquaculture with the aim to increase the production yield of quality freshwater fish while improving the welfare Communities that are still under the poverty line. The purpose of this research is to know the success of community empowerment in freshwater fish aquaculture by the government of Pasaman regency. The method of research used is a qualitative method with a descriptive approach, with data collection techniques using study literature, as well as the legality technique of data using data triangulation. The results showed that the community empowerment in freshwater fish aquaculture conducted by the Pasaman government with the community was successful with the increasing production of freshwater fish produced from 46,809 tons in the year 2013 To 51,827 tons in the year 2018, so that raising the welfare of society that previously had less than $R p 10$ million now has risen to $R p 25$ million per three months, and make Pasaman Regency one of the best areas in freshwater fish aquaculture in Indonesia.
\end{abstract}

Kata Kunci : Fish Aquaculture, Community Empowerment 


\section{PENDAHULUAN}

Permintaan akan konsumsi ikan air tawar masih tergolong tinggi pada masyarakat Kabupaten Pasaman maupun Provinsi Sumatera barat. Masyarakat Kecamatan Rao Selatan adalah salah satu penghasil ikan air tawar disamping profesi mereka sebagai petani di Kabupaten Pasaman. Hal ini didukung dengan kondisi suhu dan air yang melimpah yang sesuai dengan pembudidayaan ikan air tawar seperti ikan mas, lele, nila, dan gurame. Namun profesi tersebut belum tentu mampu meningkatkan kesejahteraan hidup masyarakatnya. Selain itu belum maksimalnya hasil produksi ikan air tawar yang dihasilkan oleh masyarakat Kecamatan Rao Selatan mendukung keterpurukan ekonomi-sosial masyarakat. Maka dari itu, disinilah berperan penting yang namanya pemberdayaan masyarakat terhadap kekayaan sumber daya yang terdapat pada Kecamatan Rao Selatan di bidang budidaya ikan air tawar, yang kemudian diharapkan mampu meningkatkan hasil produksi ikan air tawar yang berkualitas dalam upaya memenuhi kebutuhan permintaan ikan air tawar bagi masyarakat Kabupaten Pasaman dan Sumatera Barat, serta untuk meningkatkan kesejahteraan hidup khususnya untuk masyarakat Kecamatan Rao Selatan.

Dalam hal pemberdayaan masyarakat, Chamber dalam Suaib \& Siswanto (2017), berpendapat bahwa pemberdayaan masyarakat adalah konsep pembanguan ekonomi yang merangkum nilai-nilai masyarakat untuk membangun paradigma baru dalam pembangunan yang bersifat people-centered, participatory, empowerment and sustainable. Lebih jauh Chamber menjelaskan bahwa konsep pembangunan dengan model pemberdayaan masyarakat tidak hanya semata-mata memenuhi kebutuhan dasar (basic need) masyarakat tetapi lebih sebagai upaya mencari alternatif pertumbuhan ekonomi lokal. Amanah (2005) menyatakan bahwa pemberdayaan (empowerment) adalah upaya kapasitasi atau peningkatan kemampuan masyarakat baik secara sosial maupun ekonomi dengan menggunakan potensi sumber daya lokal, menempatkan orang yang diberdayakan sebagai subyek atau fokus kegiatan, sehingga masyarakat memiliki kekuatan untuk meningkatkan kualitas hidup. Intinya, pemberdayaan merupakan upaya peningkatan kekuatan (daya) masyarakat agar masyarakat tersebut mempunyai kekuatan untuk maju dan berkembang (legal power), memiliki kewenangan untuk mengambil keputusan (legal authority), dan mampu mengakses berbagai layanan publik (legal access). Dalam kaitannya dengan bidang perikanan, Mashur (2019), memaparkan pembinaan masyarakat dalam pengolahan hasil tangkap ikan dilakukan dalam tiga kegiatan inti, yakni :

1. Pembentukan skill dan pemberdayaan individu

2. Pembentukan kelompok/ pembangunan kelembagaan

3. Bantuan Manajemen

Sementara itu, mengenai pemenuhan kebutuhan akan permintaan, dapat dipahami terlebih dahulu permintaan adalah banyaknya jumlah barang yang diminta pada suatu pasar dengan tingkat harga tertentu dan tingkat pendapatan tertentu, serta dalam periode tertentu. Menurut Samuelson (2001), dalam pandangannya, permintaan adalah hubungan jelas antara harga pasar suatu barang dengan jumlah yang diminta, dengan catatan faktor lain tidak berubah. Salvatore (2006), menyatakan permintaan adalah jumlah suatu komoditi yang bersedia dibeli individu selama periode waktu tertentu merupakan fungsi dari atau tergantung pada komoditi itu, pendapatan nominal individu, harga komoditi lain, dan cita rasa individu. Dengan demikian dapat diketahui bahwa permintaan terhadap suatu barang akan berubah apabila citra rasa atau pendapatan suatu harga barang-barang lain mengalami perubahan pula.

Di Kabupaten Pasaman khususnya Kecamatan Rao Selatan, budidaya ikan air tawar menjadi salah satu mata pencaharian utama masyarakat setempat. Masyarakat memanfaatkan lahan mereka dengan merevitalisasinya menjadi tambak ikan dan mengisinya dengan berbagai jenis ikan diantaranya ikan mas, nila, lele, dan berbagai jenis ikan air tawar lainnya. Diantara banyaknya jenis ikan air tawar tersebut, ikan mas menjadi salah satu ikan yang mengalami peningkatan paling signifikan dalam permintaan di pasarannya. Hal ini tentu membawa keuntungan bagi masyarakat dari adanya pembudidayaan ini. Potensi 
budidaya ikan air tawar diutamakan pemerintah dalam proses pembudidayaan yang berkelanjutan demi pengoptimalan kuantitas dan kualitas hasil produksi ikan air tawar masyarakat, serta kualitas kesejahteraan masyarakat Kecamatan Rao Selatan itu sendiri. Pemerintah mendukung penuh pemberdayaan masyarakat terhadap budidaya ikan air tawar di Kabupaten Pasaman khususnya di Kecamatan Rao Selatan dengan dukungan sumber daya alam berupa air yang melimpah dan suhu udara yang sesuai dengan pertumbuhan ikan air tawar.

Tujuan dari adanya pemberdayaan ini adalah untuk meningkatkan produksi ikan air tawar yang akan menjawab permintaan konsumsi ikan air tawar yang cukup tinggi di Kabupaten Pasaman, Provinsi Sumatera Barat, bahkan permintaan pemasaran di daerah luar provinsi. Selain itu, dari pemberdayaan ini bisa menjadikan petani budidaya ikan air tawar lebih mandiri dengan hasil yang berkualitas. Pada pemberdayaan yang dilakukan Kabupaten Pasaman terbilang berhasil dengan semakin meningkatnya hasil produksi ikan air tawar yang dihasilkan Kecamatan Rao Selatan setiap tahunnya dan bisa dipasarkan ke provinsi tetangga seperti Provinsi Riau, Jambi, Sumatera Selatan, Sumatera Utara, dan Bengkulu. Pada tahun 2014 pun Kabupaten Pasaman merupakan tiga daerah pelaksanaan budidaya ikan yang mendapat peringkat A di Indonesia, hal ini menunjukkan tingkat keberhasilan dari konsistensi dan sinergitas setiap stakeholder dalam budidaya ikan air tawar diKabupaten Pasaman.

Pada tulisan ini akan dipaparkan mengenai bagaimana pemerintah melakukan pemberdayaan masyarakat dalam membudidayakan ikan air tawar yang terdapat di Kecamatan Rao Selatan dan keberhasilannya dalam menjalankan program pemberdayaan ini Kabupaten Pasaman. Karna kegiatan pemberdayaan ini akan bernilai nantinya untuk masyarakat dan daerah itu sendiri. Menjadi petani tambak ikan merupakan profesi masyarakat untuk memanfaatkan sumber daya alam yang ada di sekitar mereka. Seperti yang dipaparkan diatas, Kabupaten Pasaman merupakan salah satu sentral budidaya perikanan air tawar terbaik di Sumatera Barat dengan peringkat A di Indonesia. Secara ekonomi usaha perikanan di Rao Selatan berjalan cukup bagus, serta memberikan keuntungan nyata bagi para petani dan pengusaha perikanan serta mampu pula menyerap tenaga kerja yang sekaligus berperan dalam meminimalisir pengangguran.

\section{METODE}

Metode penelitian yang digunakan adalah metode kualitatif dengan pendekatan deskriptif, dengan teknik pengumpulan data menggunakan studi literatur, serta teknik keabsahan data menggunakan triangulasi data. Ruang lingkup penelitian dan fokus penelitian adalah fenomena yang terjadi di bidang perikanan terkhusus pada budidaya ikan air tawar Kecamatan Rao Selatan dan pemberdayaan masyarakat yang dilakukan pemerintah daerah setempat untuk memenuhi permintaan akan konsumsi ikan air tawar yang tinggi di Sumatera Barat dengan korelasinya untuk kesejahteraan kelompok tani ikan air tawar di Kecamatan Rao Selatan, Kabupaten Pasaman.

\section{HASIL DAN PEMBAHASAN}

\section{Gambaran Umum Budidaya Ikan di Rao Selatan}

Potensi perikanan Indonesia baik laut maupun tawar di perkirakan mencapai 65 juta ton/tahun, yang nilainya mencapai 82.064 juta USD. Dengan potensi yang begitu besar, sumber daya perikanan merupakan salah satu sektor yang dapat diandalkan bagi pembangunan dan kesejahteraan bangsa dan negara. Ini berarti bahwa potensi produksi dan pengembangan usaha perikanan masih sangat besar terutama untuk budidaya perairan, usaha pengolahan, dan industri bioteknologi kelautan dan perikanan. 
Sektor perikanan mampu menjadi andalan perekonomian nasional suatu bangsa. Dan ini bisa terjadi melalui keseriusan terhadap kinerja untuk sektor tersebut. Konsumsi ikan merupakan salah satu faktor yang dapat menjadikan sektor ini sebagai andalan.

Menurut Adi (2011), potensi sumber daya perikanan budidaya di Indonesia cukup besar dengan keragaman jenis biota air laut yang bernilai ekonomis memungkinkan untuk dibudidayakan. Namun pemanfaatannya belum dapat dimaksimalkan sehingga kontribusi sektor perikanan terhadap pembangunan dan perekonomian pada umumnya serta peningkatan taraf hidup masyarakat hidup petani ikan belum optimal. Usaha budidaya ikan air tawar semakin hari semakin menggiurkan. Menurut laporan Badan Pangan PBB, pada tahun 2021 konsumsi ikan perkapita penduduk dunia akan mencapai 19,6 kg per tahun. Meski saat ini konsumsi ikan lebih banyak dipasok oleh ikan laut, namun pada tahun 2018 produksi ikan air tawar menyalip produksi perikanan tangkap. Mengapa demikian? karena produksi perikanan tangkap akan mengalami penurunan akibat overfishing. Ikan di laut semakin sulit didapatkan. Bahkan bila tidak ada perubahan model produksi, para peneliti meramalkan pada tahun 2048 tak ada lagi ikan untuk ditangkap.

Kecamatan Rao Selatan, Kabupaten Pasaman, di bidang perikanan sendiri lebih memfokuskan kegiatan masyarakatnya pada budidaya ikan air tawar. Pada 2014 lalu pemerintah telah mengembangkan pusat pembenihan ikan melalui Dana Alokasi Khusus (DAK) berupa infrastruktur fisik yaitu pembangunan sentra pembenihan yang dikelola oleh dua kelompok tani yang dibentuk : Kelompok Harapan Tonsen dan Unit Pembenihan Rakyat (UPR) oleh Kelompok Raja Mandiri. Hal itu memberikan outcome yang menguntungkan bagi daerah tersebut hingga saat ini. Selain itu, pada tahun 2019 ini, pemerintah juga telah melakukan pengembangan dan pengelolaan dengan memaksimalkan pengoperasionalan Balai Benih Ikan (BBI) Beringin Rao, Kecamatan Rao Selatan, sebagai sentral peningkatan benih ikan dan induk ikan yang berkualitas. Potensi ikan air tawar di Kecamatan Rao Selatan sangat besar, dengan 4 hingga 7 ton hasil ikan persatu hektar lahan menjadikan taraf kesejahteraan masyarakat setempat semakin membaik. Walau terkadang harga pasar turun, tapi untuk saat ini masih relatif aman bagi petani tambak ikan. Bupati Pasaman Yusuf Lubis sangat berharap besar pada hasil budidaya ikan ait tawar ini, karena dapat meningkatkan kesejahteraan masyarakat dan membantu program pembangunan di Kabupaten Pasaman, serta berharap setiap stakeholder dapat saling terintegrasi dalam mengembangkan hasil budidaya ini.

Melihat peluang dari budidaya ikan air tawar ini, sangat menjanjikan dalam roda perekonomian masyarakat Kabupaten Pasaman terutama bagi masyarakat Kecamatan Rao Selatan. Masyarakat Rao Selatan mengawali budidaya ikan ini dari kelompok-kelompok kecil petani yang merevitalisasi lahan sawah dan kebun menjadi kolam tambak ikan. Dengan bantuan Pemerintah Kabupaten baik itu dalam mewadahi ataupun memfasilitasi budidaya ikan air tawar, kelompok tani yang telah dibentuk akan semakin semangat dalam mengembangkan potensi budidaya ikan air tawar.

Berdasarkan pendapat (Sunyoto, 2004), ada beberapa strategi yang dapat menjadi pertimbangan untuk dipilih dan kemudian diterapkan dalam pemberdayaan masyarakat yang dapat dilihat dari tiga sisi, yaitu :

a) Menciptakan suasana atau iklim yang memungkinkan potensi masyarakat berkembang (enabling). Disini titik tolaknya adalah pengenalan bahwa setiap manusia memiliki potensi atau daya yang dapat dikembangkan.

b) Memperkuat potensi atau daya yang dimiliki oleh masyarakat atau kelompok yang akan diberdayakan (empowering). Hal ini melalui peningkatan taraf pendidikan, dan derajat kesehatan, serta akses ke dalam sumber-sumber kemajuan ekonomi seperti modal, lapangan kerja, dan pasar.

c) Upaya melindungi (protect). Barkaitan dengan terjadinya persaingan yang tidak seimbang, untuk menciptakan keadilan serta menciptakan kebersamaan dan kemitraan antara yang sudah maju dengan yang belum berkembang. Selain itu juga mencegah yang lemah menjadi bertambah lemah. 
Di Kabupaten Pasaman khususnya Kecamatan Rao selatan, Pemerintah Kabupaten memfasilitasi atau memberi dukungan dalam proses pemberdayaan masyarakat melalui pengembangan budidaya ikan air tawar dalam bentuk seperti yang dipaparkan dibawah ini, yaitu :

1. Pemberian bibit unggul untuk mendukung proses pemberdayaan masyarakat dalam budidaya ikan air tawar

Melalui Dinas Perikanan Kabupaten Pasaman, masyarakat Kecamatan Rao Selatan mendapat bantuan setiap tahunnya berupa bibit ikan yang unggul. Dalam pelaksanaannya, masyarakat mendapat bibit tersertifikasi yang ada di Unit Pembinaan Rakyat (UPR) dengan pagu anggaran Rp450 juta dari Dana Alokasi Khusus (DAK). Hal tersebut diawasi langsung oleh bidang perikanan dari Dinas Perikanan Kabupaten Pasaman dengan selalu mensosialisasikan dan menganjurkan petani ikan untuk menggunakan bibit unggul yang disediakan pada UPR agar produksi ikan selalu meningkat. Hal ini sesuai dengan arahan dari Kementrian Kelautan dan Perikanan (KKP) Republik Indonesia. Langkah pemberdayaan yang dilakukan Dinas Perikanan Kabupaten Pasaman menunjukkan kolaborasi antara pemerintah dengan kelompok tani ikan yang terintegrasi dengan arahan Pemerintah Pusat yang disini diwadahi oleh Kementerian Kelautan dan Perikanan.

2. Membangun Balai Bibit Ikan (BBI) dan Kolam Pembesaran Ikan (KPI)

Dinas Pertanian Kabupaten Pasaman juga membangun Balai Bibit Ikan (BBI) dan Kolam Pembesaran Ikan (KPI) dalam pemberdayaannya terhadap masyarakat agar masyarakat dapat selalu menggunakan bibit ikan yang unggul dengan kaitannya pada poin 1. BBI Beringin Rao di Kecamatan Rao Selatan awalnya dikelola oleh Pemerintah Provinsi, dan saat ini secara resmi BBI Beringin Rao sudah dikelola oleh Pemerintah Kabupaten Pasaman. Unit Pelaksana Teknis Daerah (UPTD) ini sangat bermanfaat bagi Pemerintah untuk pemberdayaan masyarakat sehingga bisa mempercepat perkembangan usaha perikanan di Kabupaten Pasaman. UPTD tersebut terletak pada dua lokasi dengan luas sekitar 7,6 hektar dengan rincian: BBI Beringin Rao seluas 3,7 hektar dengan jumlah kolam ikan sebanyak 38 unit, kemudian untuk KPI Limau Asam seluas 3,9 hektar dengan jumlah kolam 6 unit. Selain kolam juga ada gedung kantor, rumah dinas, gudang pembuatan pakan ikan, laboratorium, ruang packing, dan hatchery (bangunan tempat memproduksi benih ikan). Masing-masing UPTD tersebut ditempatkan 4 orang pegawai Dinas Perikanan untuk ditugaskan merumuskan program dan rencana kegiatan BBI kemudian membantu masyarakat dalam memproduksi benih ikan dan induk ikan unggul, serta menyiapkan sarana dan prasarana operasional BBI.

3. Pemerintah melalui BBI melakukan pelayanan dan pendampingan kepada kelompok tani budidaya perikanan

Dalam hal ini, Pemerintah Kabupaten Pasaman (Pemkab Pasaman) melalui BBI membantu masyarakat pembudidaya, UPR, dan pelaku usaha perikanan dalam pembudidayaan ikan air tawar dengan melakukan pelayanan dan pendampingan khusus, karna BBI sendiri merupakan sentral informasi dan transfer teknologi perikanan. Pelayanan dan pendampingan dari BBI menjadi salah satu tolak ukur dalam keberhasilan pemberdayaan masyarakat budidaya ikan air tawar di Rao Selatan. Hal ini ditargetkan untuk peningkatan produksi ikan air tawar di Kabupaten Pasaman dapat tercapai dari tahun ke tahun.

\section{Hasil dan Ketercapaian Sasaran}

Hasil dan pencapaian dari bentuk fasilitasi yang diberikan Pemerintah Kabupaten Pasaman dalam mendukung pemberdayaan masyarakat melalui pengembangan budidaya ikan air tawar di Kecamatan Rao Selatan dapat dipaparkan sebagai berikut : 


\section{Kesejahteraan petani}

Dengan adanya program BBI dan KPI serta program lainnya yang diberikan pemerintah Kabupaten Pasaman dalam bidang perikanan air tawar ini memberikan outcome yang sangat baik bagi kesejahteraan masyarakat Pasaman khususnya Kecamatan Rao Selatan. Ini terbukti dengan semakin semangatnya masyarakat Rao selatan dalam membudidayakan ikan dan semakin banyaknya lahan yang direvitalisasi menjadi area kolam/tambak ikan. Dengan adanya budidaya ikan ini banyak lapangan pekerjaan yang tercipta dari distributor, supir, penjual ikan, pengolah ikan air tawar, pengusaha tambak, dll. Hal ini membuktikan bahwa masyarakat Rao selatan sudah dalam tahap mandiri dalam membudidayakan ikan air tawar dan bisa meningkatkan perekonomian mereka, serta bisa menciptakan lapangan pekerjaan dilingkungannya tersebut sehingga dapat meminimalisir adanya pengangguran di Kecamatan Rao Selatan.

\section{Peningkatan Hasil produksi}

Pada tahun 2013 hasil produksi ikan air tawar Kabupaten Pasaman berkisar pada angka 46.809 ton yang didominasi oleh Kecamatan Rao Selatan, sedangkan pada tahun 2015 mengalami peningkatan dengan angka 47.558 ton. Pada setiapnya tahunnya produksi ikan di Kabupaten Pasaman selalu meningkat, dan pada tahun 2018 produksi ikan air tawar Kabupaten Pasaman berada pada angka 51.827 ton yang kembali didominasi oleh Kecamatan Rao Selatan.

Dengan adanya program BBI dan KPI dari Dinas Perikanan Kabupaten Pasaman ini, produksi ikan air tawar selalu menunjukkan peningkatan yang signifikan setiap tahunnya. Dalam hal harga pasaran pun masih menunjukkan kestabilan dengan harga Rp18.000 - Rp28.000 perkilonya dan masih dalam harga yang menguntungkan bagi petani sehingga juga masih bisa menstabilkan harga pasaran pada masyarakat.

\section{Peningkatan Pendapatan Masyarakat}

Dengan pemberdayaan masyarakat melalui pengembangan budidaya ikan air tawar ini, mayarakat pembudidaya mengalami peningkatan yang signifikan pada penghasilan mereka yang mulanya kurang dari Rp 10 juta, menjadi Rp 25 juta pertiga bulannya. Sehingga melalui budidaya ikan air tawar ini, mulai dari proses pembenihan sampai proses produksi, tentu membawa keuntungan bagi masyarakat Kabupaten Pasaman khususnya masyarakat Rao Selatan dalam memenuhi kebutuhan dan meningkatkan kesejahteraan hidupnya.

4. Menjadi sentral produksi ikan air tawar

Pada saat ini Kabupaten Pasaman khususnya Kecamatan Rao Selatan menjadi sentral produksi ikan air tawar di Sumatera Barat. Untuk pemenuhan kebutuhan ikan di Kabupaten Pasaman sudah sangat terpenuhi dan bisa memasok kebutuhan permintaan ikan baik di dalam Provinsi Sumatera Barat maupun di luar Provinsi seperti Riau, Sumatera Utara, Bengkulu, Jambi, bahkan sampai ke Sumatera Selatan. Hal ini membuktikan bahwa produksi ikan Rao Selatan sudah mencapai tahap mandiri dalam pengembangannya sehingga hasil dari budidaya ini sangat melimpah dan bisa dipasarkan di Provinsi tetangga tanpa mengurangi pasar di dalam Kabupaten Pasaman itu sendiri. Pemerintah Kabupaten Pasaman sendiri sangat antusias dalam mendukung Kabupaten Pasaman terkhusus Kecamatan Rao Selatan menjadi sentral produksi ikan air tawar di Provinsi Sumatera Barat bahkan di Pulau Sumatera.

\section{Terakreditasi di tingkat Nasional}

Daerah Pasaman merupakan tiga daerah pelaksanaan budidaya ikan yang mendapat peringkat A di Indonesia. Dengan kerja keras dan konsistensi dari pemerintah Kabupaten Pasaman dan Masyarakat yang diberdayakan di Rao Selatan serta semua stakeholder yang terkait dalam budidaya ikan air tawar mengantarkan Kabupaten Pasaman sebagai salah satu daerah terbaik di bidang budidaya ikan di Indonesia. Hal ini membuktikan sinergitas dan kolaborasi yang 
baik antara pemerintah dan masyarakat dalam mengembangkan budidaya ikan air tawar ini. Harapan kedepannya pemberdayaan masyarakat melalui pengembangan budidaya ikan air tawar ini dapat lebih baik lagi sesuai dengan visi misi Kabupaten Pasaman dan konsentrasi Pemerintah Pusat dalam memberdayakan masyarakat sehingga sumber daya manusia unggul yang diusung dapat terwujud di Indonesia.

\section{KESIMPULAN}

Budidaya ikan air tawar menjadi salah satu ladang ekonomi yang cukup menjanjikan bagi masyarakat. Hal tersebut mendapat dukungan penuh dari pemerintah dalam memberdayakan Sumber Daya Manusia (SDM) dengan baik. Selain itu, yang menjadi daya dukung pengembangan budidaya ikan air tawar di Rao Selatan, Kabupaten Pasaman meliputi kondisi suhu air dan udara yang sesuai dengan pertumbuhan ikan air tawar dan pasokan air yang melimpah dari sungai sumpur yang melewati Kecamatan Rao Selatan. Kabupaten Pasaman sudah melihat potensi ini sejak lama dan mengembangkan budidaya ikan air tawar sehingga bisa menjadikan Kabupaten Pasaman menjadi sentral budidaya ikan air tawar terbaik di Provinsi Sumatera Barat dan bahkan di Indonesia. Kecamatan Rao Selatan menjadi kecamatan dengan penyumbang hasil produksi ikan air tawar terbesar di Kabupaten Pasaman dengan lebih dari 20 ribu ton/tahun dari total 50 ribu ton lebih hasil ikan air tawar Kabupaten Pasaman. Dengan pemberdayaan masyarakat terhadap pemenuhan kebutuhan dari pemerintah dalam budidaya ikan air tawar seperti yang telah dipaparkan pada metode penerapan dan hasil pencapaian, dapat menjadikan masyarakat mandiri dalam pengelolaan ikan air tawar di Kabupaten Pasaman terkhusus di Kecamatan Rao Selatan.

\section{SARAN}

Kabupaten Pasaman sudah menerapkan pemberdayaan masyrakat dibidang budidaya ikan air tawar secara sistematis, sinergis, dan collaborative dengan masyarakat setempat sesuai arahan Kementrian Kelautan dan Perikanan dan impact nya bagus bagi produksi ikan air tawar dan kesejahteraan masyarakat dengan memberikan ilmu budidaya serta fasilitas pembibitan yang layak tetapi masih ada permasalahan yang timbul dari budidaya ikan air tawar ini seperti pakan ikan yang mahal, irigasi yang masih kurang baik dalam mengalirkan air untuk kolam ikan, dan Pasaman masih beum mampu memproduksi pakan ikan yang berkualitas. Saran peneliti untuk menyelesaikan permasalahan ini adalah Pemerintah Pasaman mampu membangun irigasi aliran air kolam yang sistematis agar air bisa dialirkan merata pada setiap kolam ikan, Pemerintah mampu memproduksi secara mandiri pakan ikan yang berkualitas didaerah Pasaman dengan melakukan penelitian terhadap komposisi yang terkandung dalam pakan ikan yang berkualitas dengan mendatangkan ahli dibidang gizi ikan dan mensubsidinya kepada petani ikan sehingga petani dapat lebih produktif dalam budidaya ikan air tawar.

\section{DAFTAR PUSTAKA}

[1]. Adi, S. (2011). Analisa Usaha Perikanan Budidaya. Jakarta: Pusat Penyuluhan Kelautan dan Perikanan : Kementerian Kelautan dan Perikanan.

[2]. Amanah, S. (2005). Pengembangan Masyarakat Pesisir berdasarkan Kearifan Lokal di Pesisir Kabupaten Buleleng, Provinsi Bali (Doctoral dissertation). Institut Pertanian Bogor, Indonesia. 
[3]. Darmansah, A., Sulistiono, Nugroho, T., \& Supriyono, E. (2016). Pemberdayaan Masyarakat melalui Pengembangan Budi Daya Ikan Lele di Desa Balongan, Indramayu, Jawa Barat. Agrokreatif Jurnal Ilmiah Pengabdian Kepada Masyarakat, 2(1), 8. https://doi.org/10.29244/agrokreatif.2.1.8-16

[4]. Ihsan, Y. N. (2002). Kajian Pengembangan Budidaya Laut: Pengaruhnya terhadap kesejahterasaan Masyarakat Pesisir.

[5]. Mashur, D., Putra, R., Herman, H., Mayarni, M., Nasution, M., Hariyani, E., Musadad, M., \& Putri, R. (2019). Penguatan Iptek dan kearifan lokal dalam pengelolaan perikanan di Desa Pangkalan Jambi Kecamatan Bukit Batu Kabupaten Bengkalis. Unri Conference Series: Community Engagement, 1, 290-296. https://doi.org/10.31258/unricsce.1.290-296

[6]. Nasdian, F. T. (2014). Pengembangan Masyarakat. Jakarta: Yayasan Pustaka Obor Indonesia.

[7]. Noor, M. (2011). Pemberdayaan Masyarakat. Jurnal Ilmiah CIVIS, 1(2), 87-99.

[8]. Rochdianto, A. (2009). Budidaya Ikan di Jaring Terapung. Jakarta: Penebar Swadaya.

[9]. Salvatore, D. (2006). Mikroekonomi (Edisi Keem). Inc. Newyork: McGraw-Hill.

[10]. Samuelson, P. A., \& Nordhaus, W. D. (2001). Macroeconomics (Seventeent). New York: McGrawHill Higher Education.

[11]. Suaib, H., \& Siswanto, B. (2017). Suku Moi: Nilai-Nilai Kearifan Lokal dan Modal Sosial dalam Pemberdayaan Masyarakat.

[12]. Sunyoto, U. (2004). Pembangunan dan Pemberdayaan Masyarakat. Yogyakarta: Pustaka Pelajar. 